\title{
Paraneoplastic cerebellar ataxia and antibodies to metabotropic glutamate receptor 2
}

Raquel Ruiz-García, PhD, Eugenia Martínez-Hernández, MD, PhD, Bastien Joubert, MD, Mar Petit-Pedrol, PhD, Elena Pajarón-Boix, MD, Verónica Fernández, MD, Lidia Salais, MD, María del Pozo, MD,

Thais Armangué, MD, PhD, Lidia Sabater, PhD, Josep Dalmau, MD, PhD, and Francesc Graus, MD, PhD

Neurol Neuroimmunol Neuroinflamm 2020;7:e658. doi:10.1212/NXI.0000000000000658

\author{
Correspondence \\ Dr. Graus \\ francesc.graus@idibaps.org
}

\begin{abstract}
Objective

To report the presence of a new neuronal surface antibody against the metabotropic glutamate receptor 2 antibody (mGluR2-Ab) in 2 patients with paraneoplastic cerebellar ataxia.

\section{Methods}

mGluR2-Abs were initially characterized by immunohistochemistry on the rat brain and confirmed by immunofluorescence on HEK293 cells transfected with mGluR2. Additional studies included analysis of potential cross-reactivity with other mGluRs, expression of mGluR2 in patients' tumors, and the effects of mGluR2-Abs on cultures of rat hippocampal neurons.
\end{abstract}

\section{Results}

Patient 1 was a 78 -year-old woman with progressive cerebellar ataxia with an initial relapsingremitting course who developed a small-cell tumor of unknown origin. Patient 2 was a 3-yearold girl who presented a steroid-responsive acute cerebellitis preceding the diagnosis of an alveolar rhabdomyosarcoma. Patients' serum and CSF showed a characteristic immunostaining of the hippocampus and cerebellum in rat brain sections and immunolabeled the cell surface of live rat hippocampal neurons. HEK293 cells transfected with mGluR1, 2, 3, and 5 confirmed that patients' antibodies only recognized mGluR2. mGluR2-Abs were not detected in 160 controls, 120 with paraneoplastic, autoimmune, or degenerative ataxias, and 40 with autoimmune encephalitis and antibodies against mGluR5 or unknown antigens. Expression of mGluR2 in tumors was confirmed by immunohistochemistry using a commercial mGluR2-Ab. Incubation of live rat hippocampal neurons with CSF of patient 2 did not modify the density of surface mGluR2 clusters.

\section{Conclusions}

mGluR2-Abs are a novel biomarker of paraneoplastic cerebellar ataxia. The potential pathogenic effect of the antibodies is not mediated by downregulation or internalization of neuronal surface mGluR2. 


\section{Glossary}

$\mathbf{C B A}=$ cell-based assay; $\mathbf{m G l u R 2 - A b}=$ metabotropic glutamate receptor 2 antibody.

In autoimmune encephalitis, there are many autoantibodies against neuronal cell surface or synaptic receptors that associate with a good response to immunotherapy. ${ }^{1}$ However, in autoimmune cerebellar ataxias, the occurrence of similar autoantibodies is rare. Only 2 antibodies against neuronal surface antigens, and therefore potentially pathogenic, have been consistently reported: the antibodies against voltage-gated calcium channels in patients with small-cell lung cancer and the antibodies against the metabotropic glutamate receptor (mGluR) 1 in patients with autoimmune ataxia. ${ }^{2}$ Here, we report 2 patients with cerebellar ataxia and cancer who presented mGluR2 antibodies (mGluR2-Abs).

\section{Methods}

\section{Immunologic studies}

Serum and CSF from the 2 patients were examined by immunohistochemistry on frozen sections of the rat brain and by indirect immunofluorescence on cell-based assays (CBAs) using unfixed HEK293 cells transfected with plasmids encoding mGluR1, 2, 3, and 5 as reported. ${ }^{3,4}$ In addition, serum or CSF from 160 patients, 120 with cerebellar ataxias (paraneoplastic: 58; pediatric cerebellitis: 32; degenerative: 20; with mGluR1 antibodies: 10), 10 patients with autoimmune encephalitis with mGluR5 antibodies, and 30 patients with autoimmune encephalitis and antibodies against unknown antigens were tested with CBA of mGluR2. mGluR2-Ab effects were examined in cultures of rat hippocampal neurons. CSF (dilution 1:10 in culture medium) of patient 2 or control CSF was added to the culture media for 48 hours. After removing the media, neurons were sequentially incubated with mGluR2-Ab-positive $\operatorname{CSF}(1: 50)$ for 1 hour at $37^{\circ} \mathrm{C}$, followed by a secondary anti-human Immunoglobulin G (IgG) Alexa Fluor 488 (Invitrogen A11013, 1: $1,000)$ and the mGluR2 clusters quantified as previously described. ${ }^{5}$

To demonstrate the expression of mGluR2 in the tumor, paraffin sections were deparaffinized, incubated with a commercial mGluR2-Ab (Cell Signaling Technology), and developed with the avidin-biotin technique (Vector Labs). Specificity of the tumor immunoreactivity was confirmed by adsorption of the antibody with HEK293 cells transfected with mGluR2 or with plasmids without insert.

\section{Standard protocol approvals, registrations, and patient consents}

The Ethic Committee of the Hospital Clinic approved the study. All patients or proxies gave written informed consent for the storage and use samples and clinical information for research purposes.

\section{Data availability}

All data are reported within the article and available anonymized by request from qualified investigators.

\section{Results}

\section{Patient 1}

A 78-year-old woman presented with a 3-year history of cerebellar ataxia. During the first 2 years, she had relapsing episodes of gait instability and dysarthria that spontaneously improved in a few days. In the last year, she developed progressive ataxia that did not respond to IV immunoglobulins or corticosteroids and only partially to 1 cycle of rituximab. The brain MRI showed focal hyperintense cerebellar lesions in T2-weighted images that later evolved to diffuse involvement of the cerebellar white matter (figure 1). Three years after symptom onset, a right inguinal adenopathy was identified, which biopsy demonstrated a small-cell neuroendocrine cancer of unknown origin. Despite palliative chemotherapy, the patient died a few months after tumor diagnosis.

\section{Patient 2}

In September 2018, a 3-year-old girl presented with a 3-day history of fever, nausea, and vomiting, followed by somnolence and gait instability. Neurologic examination disclosed irritability, dysarthria, horizontal right-beating nystagmus, limb and truncal ataxia, and broad-based gait requiring bilateral support. The CSF was normal, and brain MRI showed patchy gadolinium enhancement in the cerebellar folia. She was treated with IV methylprednisolone and immunoglobulins with full recovery. In January 2019, she was diagnosed with alveolar rhabdomyosarcoma of the right axillary region with positive regional lymph nodes but without distant metastasis. The patient did not present a relapse of the cerebellar ataxia.

\section{Immunologic findings}

Serum and CSF of the 2 patients showed an identical staining of the cerebellum and hippocampus and immunolabeled the cell surface of live rat hippocampal neurons. In the cerebellum, the staining was limited to the granular cell layer with robust immunoreactivity of neuronal processes along with dendrites from cells immediately below the Purkinje cells extending into the molecular layer. In the hippocampus, there was a strong staining of the stratum moleculare with the exception of its innermost part, the stratum lacunosum moleculare, the stratum pyramidale of CA3, and CA4, and the hilus (figure 2, A-C). This immunohistochemical pattern had not been previously seen during the screening of more than 4,000 samples that we receive annually for the detection of neuronal antibodies. In contrast, we found that the immunostaining was very similar to that shown by a commercial mGluR2-Ab (figure 2, D and E). ${ }^{6}$ Serum and CSF of the 2 patients were reactive with HEK293 cells expressing mGluR2 but not with cells expressing mGluR1, 3, or 5 (figure 2, F-I). IgG subclass analysis showed that IgG1 was the predominant type in the 2 

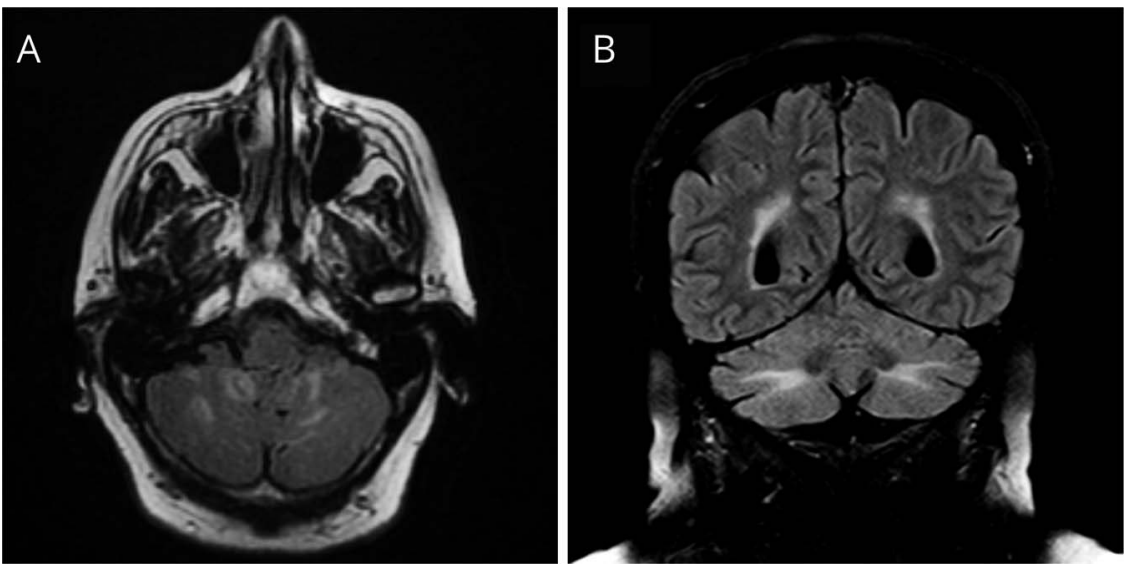

Brain MRI obtained in 2016 showed multiple FLAIR hyperintensities that did not enhance with gadolinium and involved the inferior part of the cerebellar hemispheres (A). A follow-up MRI in 2018 showed a more diffuse FLAIR hyperintensity in the white matter of the cerebellar hemispheres (B).

patients. None of the 160 controls were positive in the CBA of mGluR2.

Expression of mGluR2 was observed in both tumors as a granular immunoreactivity that was probably located in the membrane and cytoplasm (figure 3, B and D). This reactivity was not observed when the commercial mGluR2-Ab was preadsorbed with HEK293 cells transfected with mGluR2 (figure 3, A and C). Incubation of rat hippocampal neurons with patients' CSF for 48 hours did not result in a change of surface density of mGluR2 clusters (data not shown).

\section{Discussion}

This study characterizes a novel neuronal surface antibody against mGluR2 in patients with cerebral ataxia and cancer. mGluR2-Abs probably recognize epitopes in the

Figure 2 Reactivity of patients' antibodies with rat brain and HEK293 cells transfected with metabotropic glutamate receptors (mGluR)
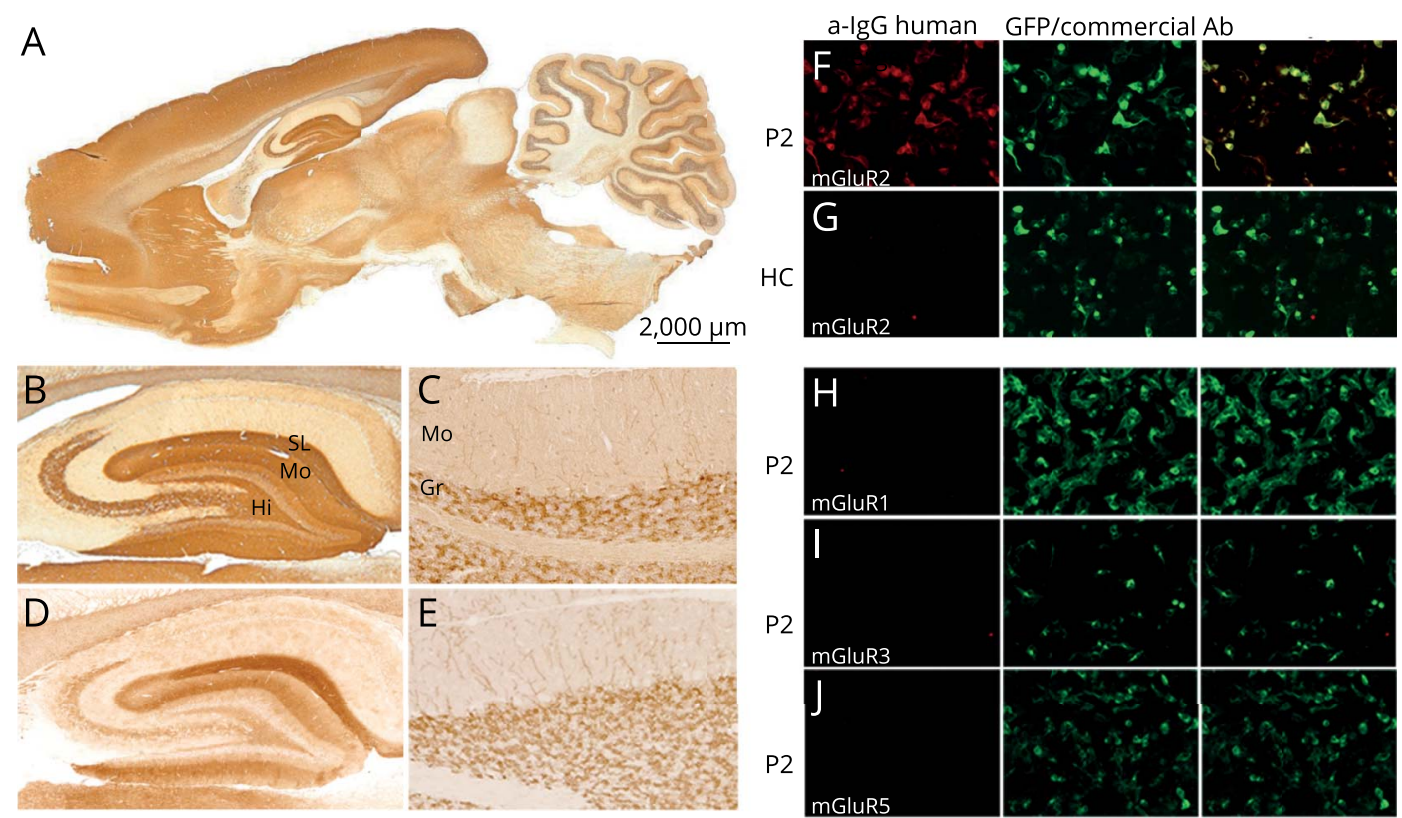

Sagittal section of rat brain immunolabeled with CSF of patient 1 (A and B). Note the intense staining of the molecular layer (Mo), stratum lacunosum molecular (SL), and hilus (Hi), as well as the stratum pyramidale of CA3 and CA4 of the rat hippocampus. In the paraformaldehyde-perfused rat cerebellum, CSF of patient 1 shows reactivity with granular layer (Gr) neurons and dendrites extending into the molecular layer (Mo) (C). Identical immunoreactivity with the hippocampus and cerebellum is observed with a commercial mGluR2-Ab (D and E). Immunostaining of live HEK293 cells expressing mGluR2 with serum from patient 2 (P2) or a healthy control $(\mathrm{HC}$ ) is shown in panels F and G. P2 serum intensely labels mGluR2-expressing cells (in red; $F$ ), whereas the HC serum is negative (G). P2 serum did not react with HEK293 cells transfected with mGluR1, mGluR3, or mGluR5, all 3 tagged with green fluorescent protein (GFP) (H-J). 

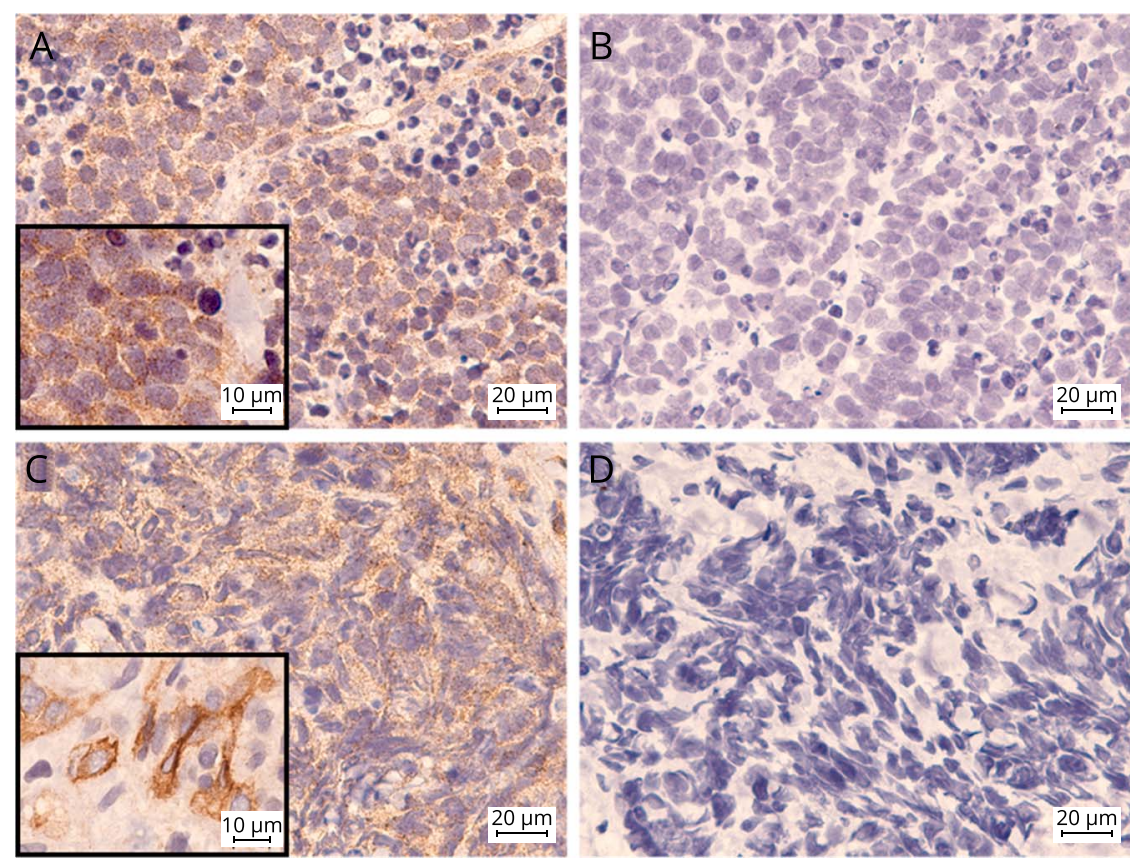

mGluR2 expression in tumors of patients 1 ( $A$ and $B$ ) and 2 (C and D). A commercial mGluR2-Ab shows a granular reactivity with the cytoplasm and probably the membrane of tumor cells as demonstrated in detail in the insets ( $A$ and $C)$. This reactivity was abrogated when the antibody was preadsorbed with HEK293 cells transfected with mGluR2 (B and D). extracellular region of the receptor as supported by the immunolabeling of live nonpermeabilized neuronal cultures. Unlike classical paraneoplastic cerebellar degeneration associated with onconeural antibodies against intracellular antigens, the clinical symptoms of patient 2 responded to immunotherapy suggesting a potential pathogenic role of mGluR2-Abs.

There are 8 subtypes of mGluRs divided in 3 subgroups according to amino acid homologies and interaction with intracellular second messengers. Group I includes mGluR1 and 5 , and both are autoimmune targets in cerebellar ataxia and encephalitis associated with Hodgkin lymphoma, respectively. ${ }^{5,7}$ Group II comprises mGluR2 and 3, whereas group III includes the remaining subtypes. ${ }^{8}$ The main physiologic role of mGluR2 is to modulate glutamatergic and GABAergic synaptic transmission. ${ }^{8}$ mGluR2-Abs could potentially alter these functions resulting in cerebellar ataxia. Different from autoantibodies directed against ion channel coupled receptors (e.g., N-methyl D-aspartate receptor), which cause internalization of the corresponding targets, our patients' mGluR2-Ab did not cause reduction of the surface receptor. An alternative possibility is that the antibodies block the function of the channel as has been proposed for other metabotropic receptors such as the gamma-aminobutyric acid b receptor. ${ }^{1}$ Future studies should determine whether passive transfer of antibodies to animals causes ataxia, as demonstrated with anti-mGluR1-Ab. ${ }^{7}$ Interestingly, rats lacking mGluR2 display behavioral symptoms but not cerebellar ataxia, suggesting that mGluR2-Ab and genetic deletion of mGluR2 may have different effects. There is precedence for this; for example, genetic and immunologic models of antiLGI1 have different phenotypes. Although the genetic abrogation of LGI1 associates with a lethal epileptic phenotype, animals infused with LGI1 antibodies develop severe memory deficits without clinical seizures. ${ }^{9}$

mGluRs are overexpressed in several types of cancer, particularly primary brain tumors, and they seem to be implicated in the regulation of cancer cell proliferation. ${ }^{10}$ Our studies show that mGluR2 was expressed by the tumor of both patients. In line with our findings, mGluR2 expression has also been found expressed in lung cancer and rhabdomyosarcoma cell lines. $^{10}$

The task for the future is to confirm our findings with additional patients and elucidate the pathogenic role of mGluR2Ab. However, the current study has practical clinical implications: (1) mGluR2-Abs may occur in patients with autoimmune cerebellar symptoms, (2) detection of these antibodies suggest that the syndrome may respond to immunotherapy, and (3) patients should be examined for the presence of an underlying tumor.

\section{Acknowledgment}

The authors thank Mrs. Eva Caballero for her excellent technical support.

\section{Study funding}

This study was supported in part by Fondo de Investigaciones Sanitarias, FEDER, Spain (FIS 14/00203, J.D.; FIS 18/00067 L.S.), NIH RO1NS077851 (J.D.), and Fundació Cellex (J.D.). 
E. Martínez-Hernández is a recipient of a Juan Rodés grant (JR17/00012) from the Instituto de Salud Carlos III, Spain.

\section{Disclosure}

R. Ruiz-Garcia, B. Joubert, E. Martínez-Hernánde, M. PetitPedrol, E. Pajarón-Boix, V. Fernández, L. Salais, M. del Pozo, T. Armangué, and L. Sabater report no disclosures. J. Dalmau receives royalties from Athena Diagnostics for the use of $\mathrm{Ma} 2$ as an autoantibody test and from Euroimmun for the use of NMDA, GABAB receptor, GABAA receptor, DPPX and IgLON5 as autoantibody tests. He is the editor of Neurology: Neuroimmunology \& Neuroinflammation. F. Graus receives royalties from Euroimmun for the use of IgLON5 as an autoantibody test and honoraria for Assistant Editor of MedLink Neurology. Go to Neurology.org/NN for full disclosures.

\section{Publication history}

Received by Neurology: Neuroimmunology \& Neuroinflammation November 5, 2019. Accepted in final form November 18, 2019.

Appendix Authors

\begin{tabular}{|c|c|c|c|}
\hline Name & Location & Role & Contribution \\
\hline $\begin{array}{l}\text { Raquel } \\
\text { Ruiz-Gracía, } \\
\text { PhD }\end{array}$ & $\begin{array}{l}\text { Hospital Clínic, } \\
\text { Barcelona, Spain }\end{array}$ & Author & $\begin{array}{l}\text { Designed and } \\
\text { conceptualized the } \\
\text { study; analyzed the } \\
\text { data; } \\
\text { immunohistochemical } \\
\text { studies; drafted the } \\
\text { first version of the } \\
\text { manuscript; and } \\
\text { revised the manuscript } \\
\text { for intellectual content }\end{array}$ \\
\hline $\begin{array}{l}\text { Eugenia } \\
\text { Martínez- } \\
\text { Hernández, } \\
\text { MD, PhD }\end{array}$ & $\begin{array}{l}\text { Hospital Clínic and } \\
\text { IDIBAPS, Barcelona, } \\
\text { Spain }\end{array}$ & Author & $\begin{array}{l}\text { Acquisition of clinical } \\
\text { data; analysis and } \\
\text { interpretation of the } \\
\text { data; and revised the } \\
\text { manuscript for } \\
\text { intellectual content }\end{array}$ \\
\hline $\begin{array}{l}\text { Bastien } \\
\text { Joubert, MD }\end{array}$ & $\begin{array}{l}\text { IDIBAPS, Barcelona, } \\
\text { Spain }\end{array}$ & Author & $\begin{array}{l}\text { Analysis of antibody } \\
\text { effects and revised the } \\
\text { manuscript for } \\
\text { intellectual content }\end{array}$ \\
\hline $\begin{array}{l}\text { Mar Petit- } \\
\text { Pedrol, PhD }\end{array}$ & $\begin{array}{l}\text { IDIBAPS, Barcelona, } \\
\text { Spain }\end{array}$ & Author & $\begin{array}{l}\text { Analysis of antibody } \\
\text { effects and revised the } \\
\text { manuscript for } \\
\text { intellectual content }\end{array}$ \\
\hline $\begin{array}{l}\text { Elena } \\
\text { Pajarón- } \\
\text { Boix, MD }\end{array}$ & $\begin{array}{l}\text { Hospital General } \\
\text { Castellón, Spain }\end{array}$ & Author & $\begin{array}{l}\text { Acquisition of clinical } \\
\text { data; analysis and } \\
\text { interpretation of the } \\
\text { data; and revised the } \\
\text { manuscript for } \\
\text { intellectual content }\end{array}$ \\
\hline $\begin{array}{l}\text { Verónica } \\
\text { Fernández, } \\
\text { MD }\end{array}$ & $\begin{array}{l}\text { Hospital General } \\
\text { Albacete, Spain }\end{array}$ & Author & $\begin{array}{l}\text { Acquisition of clinical } \\
\text { data; analysis and } \\
\text { interpretation of the } \\
\text { data; and revised the } \\
\text { manuscript for } \\
\text { intellectual content }\end{array}$ \\
\hline
\end{tabular}

Appendix (continued)

\begin{tabular}{|c|c|c|c|}
\hline Name & Location & Role & Contribution \\
\hline $\begin{array}{l}\text { María Del } \\
\text { Pozo, MD }\end{array}$ & $\begin{array}{l}\text { Hospital General } \\
\text { Albacete, Spain }\end{array}$ & Author & $\begin{array}{l}\text { Acquisition of clinical } \\
\text { data; analysis and } \\
\text { interpretation of the } \\
\text { data; and revised the } \\
\text { manuscript for } \\
\text { intellectual content }\end{array}$ \\
\hline $\begin{array}{l}\text { Lidia Salais, } \\
\text { MD }\end{array}$ & $\begin{array}{l}\text { Hospital General } \\
\text { Castellón, Spain }\end{array}$ & Author & $\begin{array}{l}\text { Acquisition of clinical } \\
\text { data; analysis and } \\
\text { interpretation of the } \\
\text { data; and revised the } \\
\text { manuscript for } \\
\text { intellectual content }\end{array}$ \\
\hline $\begin{array}{l}\text { Thais } \\
\text { Armangué, } \\
\text { MD, PhD }\end{array}$ & $\begin{array}{l}\text { IDIBAPS, Barcelona, } \\
\text { Spain }\end{array}$ & Author & $\begin{array}{l}\text { Acquisition of clinical } \\
\text { data; analysis and } \\
\text { interpretation of the } \\
\text { data; and revised the } \\
\text { manuscript for } \\
\text { intellectual content }\end{array}$ \\
\hline $\begin{array}{l}\text { Lidia } \\
\text { Sabater, } \\
\text { PhD }\end{array}$ & $\begin{array}{l}\text { IDIBAPS, Barcelona, } \\
\text { Spain }\end{array}$ & Author & $\begin{array}{l}\text { Acquisition of clinical } \\
\text { data; analysis and } \\
\text { interpretation of the } \\
\text { data; obtained } \\
\text { funding; and revised } \\
\text { the manuscript for } \\
\text { intellectual content }\end{array}$ \\
\hline $\begin{array}{l}\text { Josep } \\
\text { Dalmau, } \\
\text { MD, PhD }\end{array}$ & $\begin{array}{l}\text { Hospital Clínic, } \\
\text { ICREA Barcelona, } \\
\text { Spain and University } \\
\text { of Pennsylvania, PA, } \\
\text { USA }\end{array}$ & Author & $\begin{array}{l}\text { Acquisition of clinical } \\
\text { data; review of clinical } \\
\text { data; drafted the first } \\
\text { version of the } \\
\text { manuscript; revised } \\
\text { the manuscript for } \\
\text { intellectual content; } \\
\text { and obtained funding }\end{array}$ \\
\hline $\begin{array}{l}\text { Francesc } \\
\text { Graus, MD, } \\
\text { PhD }\end{array}$ & $\begin{array}{l}\text { IDIBAPS, Barcelona, } \\
\text { Spain }\end{array}$ & Author & $\begin{array}{l}\text { Designed and } \\
\text { conceptualized the } \\
\text { study; acquisition of } \\
\text { clinical data; review of } \\
\text { clinical data; analysis } \\
\text { and interpretation of } \\
\text { the data; revised the } \\
\text { manuscript for } \\
\text { intellectual content; } \\
\text { and wrote the final } \\
\text { version }\end{array}$ \\
\hline
\end{tabular}

\section{References}

1. Dalmau J, Geis C, Graus F. Autoantibodies to synaptic receptors and neuronal cell surface proteins in autoimmune diseases of the central nervous system. Physiol Rev 2017;97:839-887.

2. Joubert B, Rostásy K, Honnorat J. Immune-mediated ataxias. Handb Clin Neurol 2018;155:313-332.

3. Ances BM, Vitaliani R, Taylor RA, et al. Treatment-responsive limbic encephalitis identified by neuropil antibodies: MRI and PET correlates. Brain 2005;128:1764-1777.

4. Dalmau J, Gleichman AJ, Hughes EG, et al. Anti-NMDA-receptor encephalitis: case series and analysis of the effects of antibodies. Lancet Neurol 2008;7:1091-1098.

5. Spatola M, Sabater L, Planagumà J, et al. Encephalitis with mGluR5 antibodies: symptoms and antibody effects. Neurology 2018;90:e1964-e1972.

6. Shigemoto R, Kinoshita A, Wada E, et al. Differential presynaptic localization of metabotropic glutamate receptor subtypes in the rat hippocampus. J Neurosci 1997; 17:7503-7522.

7. Sillevis Smitt P, Kinoshita A, De Leeuw B, et al. Paraneoplastic cerebellar ataxia due to autoantibodies against a glutamate receptor. N Engl J Med 2000;342:21-27.

8. Ferraguti F, Shigemoto R. Metabotropic glutamate receptors. Cell Tissue Res 2006; 326:483-504.

9. Petit-Pedrol M, Sell J, Planaguma J, et al. LGI1 antibodies alter Kv1.1 and AMPA receptors changing synaptic excitability, plasticity and memory. Brain 2018;141: 3144-3159.

10. Yu LJ, Wall BA, Wangari-Talbot J, Chen S. Metabotropic glutamate receptors in cancer. Neuropharmacology 2017;115:193-202. 


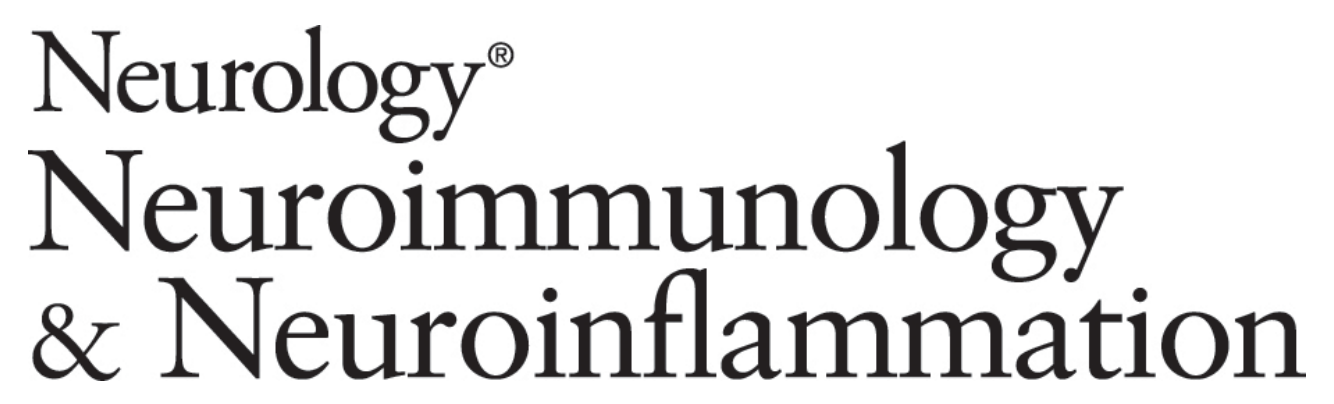

Paraneoplastic cerebellar ataxia and antibodies to metabotropic glutamate receptor 2 Raquel Ruiz-García, Eugenia Martínez-Hernández, Bastien Joubert, et al.

Neurol Neuroimmunol Neuroinflamm 2020;7;

DOI 10.1212/NXI.0000000000000658

This information is current as of December 11, 2019

Neurol Neuroimmunol Neuroinflamm is an official journal of the American Academy of Neurology.

Published since April 2014, it is an open-access, online-only, continuous publication journal. Copyright

Copyright $\odot 2019$ The Author(s). Published by Wolters Kluwer Health, Inc. on behalf of the American

Academy of Neurology.. All rights reserved. Online ISSN: 2332-7812.

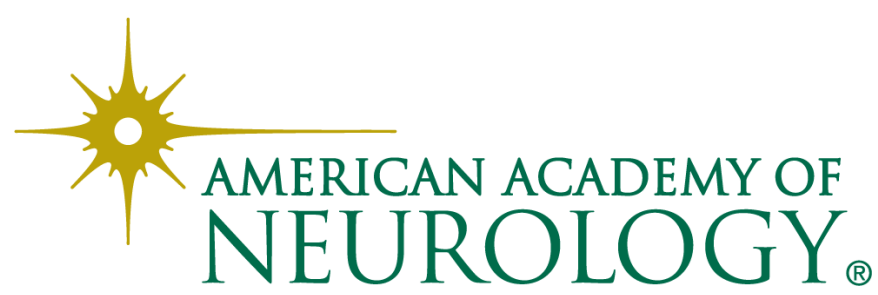




\section{Updated Information \& Services}

References

Subspecialty Collections

Permissions \& Licensing

Reprints including high resolution figures, can be found at:

http://nn.neurology.org/content/7/2/e658.full.html

This article cites 10 articles, 1 of which you can access for free at: http://nn.neurology.org/content/7/2/e658.full.html\#\#ref-list-1

This article, along with others on similar topics, appears in the following collection(s):

\section{Autoimmune diseases}

http://nn.neurology.org//cgi/collection/autoimmune_diseases

\section{Clinical neurology examination}

http://nn.neurology.org//cgi/collection/clinical_neurology_examination

Diagnostic test assessment

http://nn.neurology.org//cgi/collection/diagnostic_test_assessment_ Gait disorders/ataxia

http://nn.neurology.org//cgi/collection/gait_disorders_ataxia

Paraneoplastic syndrome

http://nn.neurology.org//cgi/collection/paraneoplastic_syndrome

Information about reproducing this article in parts (figures,tables) or in its entirety can be found online at:

http://nn.neurology.org/misc/about.xhtml\#permissions

Information about ordering reprints can be found online:

http://nn.neurology.org/misc/addir.xhtml\#reprintsus

Neurol Neuroimmunol Neuroinflamm is an official journal of the American Academy of Neurology.

Published since April 2014, it is an open-access, online-only, continuous publication journal. Copyright

Copyright $\odot 2019$ The Author(s). Published by Wolters Kluwer Health, Inc. on behalf of the American

Academy of Neurology.. All rights reserved. Online ISSN: 2332-7812.

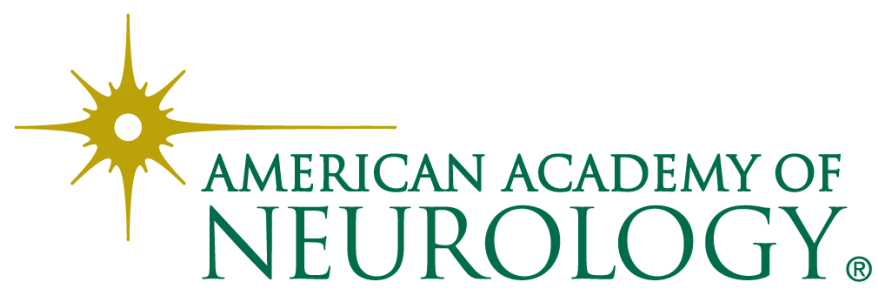

